\title{
Simulation of carbon, nitrogen and sulphur conversion in batch-operated experimental wetland mesocosms
}

\section{Authors: Njenga Mburu, David Sanchez-Ramos, Diederik P.L. Rousseau, Johan J.A. van Bruggen, George Thumbi, Otto R. Stein, Paul B. Hook, \& Piet} N.L. Lens

NOTICE: this is the author's version of a work that was accepted for publication in Ecological Engineering. Changes resulting from the publishing process, such as peer review, editing, corrections, structural formatting, and other quality control mechanisms may not be reflected in this document. Changes may have been made to this work since it was submitted for publication. A definitive version was subsequently published in Ecological Engineering, 42, May 2012. DOI\#10.1016/j.ecoleng.2012.02.003.

Mburua N, Sanchez-Ramos D, Rousseaua DPL, van Bruggena JJA, Thumbie G, Stein OR, Hook PB, Lens PNL, "Simulation of carbon, nitrogen and sulphur conversion in batch-operated experimental wetland mesocosms," Ecological Engineering, May 2012 42:304-315 


\title{
Simulation of carbon, nitrogen and sulphur conversion in batch-operated experimental wetland mesocosms
}

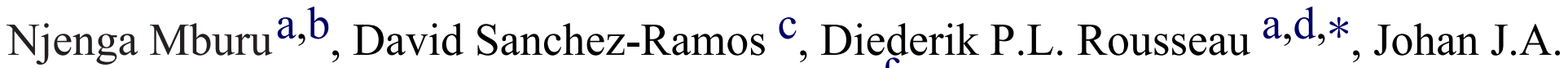 \\ van Bruggen ${ }^{\mathrm{a}}$, George Thumbi ${ }^{\mathrm{e}}$, Otto R. Stein ${ }^{\mathrm{f}}$, Paul B. Hook $\mathrm{g}$, Piet N.L. Lens ${ }^{\mathrm{a}}$ \\ ${ }^{a}$ UNESCO-IHE, Institute for Water Education, P.O. Box 3015, 2601DA Delft, The Netherlands \\ ${ }^{b}$ Department of Civil and Structural Engineering, Masinde Muliro University of Science and Technology, P.O. Box 190 50100, Kakamega, Kenya \\ ${ }^{c}$ Regional Centre of Water Research, University of Castilla La Mancha, Avda. Camilo José Cela s/n, 13071 Ciudad Real, Spain \\ d University College West Flanders, Graaf Karel de Goedelaan 5, 8500 Kortrijk, Belgium \\ e Department of Civil and Environmental Engineering, Kenya Polytechnic University College, P.O. Box 52428-00200, Nairobi, Kenya

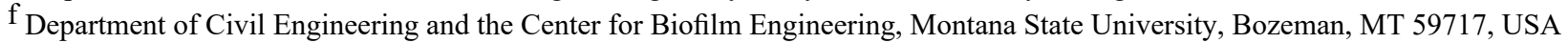 \\ g Biofilm Engineering and Affiliate Faculty Department of Land Resources and Environmental Science, Montana State University, Bozeman, MT 59717, \\ USA
}

\begin{abstract}
A simulation model based on Constructed Wetland Model No. 1 (CWM1) using the AQUASIM mixed reactor compartment as a platform was built to study the dynamics of key processes governing COD and nutrient removal in wetland systems. Data from 16 subsurface-flow wetland mesocosms operated under controlled greenhouse conditions with three different plant species (Typha latifolia, Carex rostrata, Schoenoplectus acutus) and an unplanted control were used for calibration and validation in this mechanis-tic model. Mathematical equations for plant related processes (growth, physical degradation, decay, and oxygen leaching), physical re-aeration, as well as adsorption and desorption processes for COD and ammo-nium were included and implemented alongside CWM1 in the AQUASIM software, while some CWM1 parameters were adjusted to better fit the model predictions to experimental data during calibration. The simulation results showed that the model was able to describe the general trend of $\operatorname{COD}\left(\mathrm{R}^{2}=0.97-0.99\right)$, ammonium $\left(\mathrm{R}^{2}=0.85-0.97\right)$ and

sulphate $\left(\mathrm{R}^{2}=0.71-0.93\right)$ removal in the wetland mesocosms and also in their controls (unplanted) through the experimental temperature range of $12-24{ }^{\circ} \mathrm{C}$. Oxygen transfer by physical re-aeration was found to be 0.05 and $0.09 \mathrm{~g} \mathrm{~m}^{-2}$ $\mathrm{d}^{-1}$ at $12{ }^{\circ} \mathrm{C}$ and $24{ }^{\circ} \mathrm{C}$, respectively. The amount of root oxygen transfer was the highest for the planted mesocosms at 12 ${ }^{\circ} \mathrm{C}$ at rates of $1.91,0.94$, and $0.45 \mathrm{~g} \mathrm{~m}^{-2} \mathrm{~d}^{-1}$ in the Carex, Schoenoplectus and Typha mesocosms, respectively, indicating that COD of the bulk wastewater was removed mainly by anaerobic processes under the specific experimental situations.

Measured COD removal was better in the planted mesocosms than in the control; differences were effec-tively modelled by varying the bacteria concentration. The sorption process was found to be important in simulating COD and ammonia removal under these experimental conditions.
\end{abstract}

\section{Introduction}

Constructed wetlands (CWs) are an increasingly important technical option for wastewater treatment and re-use in both developing and developed countries (Haberl, 1999; Kivaisi, 2001; Solano et al., 2004). They are potential alternative sanitation sys-tems as they are treatment cost-effective with a potential for resource re-use and recovery (Puigagut et al., 2007). However, the technical development of these systems in terms of design guide-lines is limited as the design equations of these systems are still based on empirical rules of thumb and or simple firstorder decay models (Kadlec, 2000; Moutsopoulos et al., 2011; Rousseau et al., 2004). These design models, mainly based on input-output data from CWs, provide limited insights into the performance aspects of CWs. The models are significantly site specific as they have parame-ters that have been derived from experiments with pilot CWs. Thus, the parameters are only valid for the specific boundary conditions for which they have been obtained. This defeats the goal of sound designs and successful replication and optimization of $\mathrm{CW}$ systems, an important aspect if the systems are to have public and institu-tional support. Consequently, the desire for a model that can be applied widely to various conditions encountered in the design and 


\section{Nomenclature \\ b_H rate constant for lysis of heterotrophic bacteria (1/d) \\ $K_{-} H_{1} \quad$ hydrolysis rate constant (1/d) \\ K_OAMB oxygen saturation/inhibition coefficient for ace- totrophic methanogenic bacteria $\left(\mathrm{mg} \mathrm{O}_{2} / \mathrm{l}\right)$ \\ K_SAMB acetate saturation/inhibition coefficient for ace- totrophic methanogenic bacteria $\left(\mathrm{mg} \mathrm{COD}_{\mathrm{SA}} / \mathrm{l}\right)$ \\ K_SFB fermentable COD saturation/inhibition coefficient for fermenting bacteria $\left(\mathrm{mg} \mathrm{COD}_{\mathrm{SF}} / \mathrm{l}\right)$ \\ $K \_$SOASRB sulphate saturation/inhibition coefficient for ace- totrophic sulphate reducing bacteria $(\mathrm{mg} \mathrm{S} / \mathrm{l})$ \\ $K X \quad$ saturation/inhibition coefficient for hydrolysis ( $\mathrm{gCOD}_{\mathrm{SF}} / \mathrm{gCOD}_{\mathrm{BM}}$ ) \\ $\mu$ AMB maximum growth rate for acetotrophic methanogenic bacteria $(1 / \mathrm{d})$ \\ $\mu$ ASRB maximum growth rate for acetotrophic sulphate reducing bacteria $(1 / \mathrm{d})$ \\ $\mu_{\_} \mathrm{H} \quad$ maximum aerobic growth rate on fermentable COD and acetate for heterotrophic bacteria $(1 / \mathrm{d})$ \\ $\mu$ _FB maximum growth rate for fermenting bacteria $(1 / \mathrm{d})$ \\ $Y \_$AMB yield coefficient for acetotrophic methanogenic bacteria $\left(\mathrm{g} \mathrm{COD}_{\mathrm{BM}} / \mathrm{gCOD}_{\mathrm{SA}}\right)$ \\ $Y$ ASRB yield coefficient for acetotrophic sulphur reducing bacteria $\left(\mathrm{g} \mathrm{COD}_{\mathrm{BM}} / \mathrm{g}_{\mathrm{COD}} \mathrm{SA}\right)$ \\ $Y$ FB yield coefficient for fermenting bacteria ( $\mathrm{gCOD}_{\mathrm{BM}} / \mathrm{gCOD}_{\mathrm{SF}}$ )

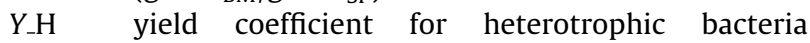 $\left(\mathrm{gCOD}_{\mathrm{BM}} / \mathrm{gCOD}_{\mathrm{SF}}\right)$}

evaluation of constructed wetland systems has recently led to the pursuit of process-based models that describe the main processes in constructed wetlands in detail.

By describing the pollutant transformation and elimination processes taking place within the CWs, coupled to the hydraulic behaviour of the CW's flow field, process-based or mechanistic models are a promising tool for understanding the parallel processes and interactions occurring in wetlands (Kumar and Zhao, 2011; Langergraber, 2007, 2008; Llorens et al., 2011a). This is anticipated to promote an increased understanding of the performance aspects and a sound conceptualization and design of constructed wetland systems. One such processes based model is the Constructed Wetland Model No. 1 (CWM1) whose formulation is based on previous experiences of modelling processes in subsurface flow constructed wetlands as reviewed in Langergraber (2008). CWM1 is a general biokinetic model to describe biochemical transformation and degradation processes for organic matter, nitrogen and sulphur in subsurface flow constructed wetlands. The mathematical structure of CWM1 is based on the mathematical formulation of Activated Sludge Models (ASMs) as introduced by the IWA task group on mathematical modelling for design and operation of biological wastewater treatment. The reaction scheme, rate equations and kinetic constants of CWM1 describe aerobic, anoxic and anaerobic processes, and is therefore applicable to both horizontal and vertical flow constructed wetland systems; however other extra processes including porous media hydrodynamics (effect of dispersion, heterogeneity and dead zones), the influence of plants, the transport of particles/suspended matter to describe clogging processes, adsorption and desorption processes and physical reaeration must be considered for the formulation of a full model of constructed wetlands (Langergraber et al., 2009; Llorens et al., 2011b).
The main scope of this study was to implement CWM1 in the software for identification and simulation for aquatic systems, AQUASIM (Reichert, 1995), to simulate carbon, nitrogen and sulphur removal in constructed wetland systems. Besides the biochemical transformation and degradation processes described in CWM1, the influence of plants, physical re-aeration, adsorption and desorption processes have been considered. The model is used here to analyse the interactions between water, the granular substratum, macrophytes, and microorganisms for pollutant transformation and degradation, in batch-operated constructed wetland mesocosms, under a range of temperatures. Batch operation has the advantage of simplifying the hydraulics when integrating transport and transformation processes in porous media that are otherwise solved with advection-dispersion-reaction equations in 1D or 2D. The calibration of the CWM1-AQUASIM model is achieved here by adaptation of the model to fit actual data from constructed wetland mesocosm experiments, with the aid of sensitivity analysis and parameter estimation tools in AQUASIM. Biofilm development is not considered in the present work.

\section{Materials and methods}

\subsection{The experimental constructed wetlands}

The experimental constructed wetlands were operated under controlled greenhouse conditions at Montana State University in Bozeman, Montana, USA. Details of column design, construction and planting, as well as sampling and measurement, are fully described in Allen et al. (2002) and Stein et al. (2006). Briefly, 16 subsurface constructed wetland mesocosms were constructed from polyvinyl chloride (PVC) pipe $(60 \mathrm{~cm}$ in height $\times 20 \mathrm{~cm}$ in diameter) and filled to a depth of $50 \mathrm{~cm}$ with washed pea-gravel $(0.3-1.3 \mathrm{~cm}$ in diameter). Four columns each were planted with Carex utriculata (Northwest Territory sedge), Schoenoplectus acutus (hardstem bulrush) and Typha latifolia (broadleaf cattail), while four were left unplanted as controls. A series of 20-d incubations with artificial wastewater was conducted over 20 months at temperatures ranging from 4 to $24^{\circ} \mathrm{C}$ at $4{ }^{\circ} \mathrm{C}$ steps. A synthetic wastewater simulating secondary domestic effluent was used with mean influent concentrations of $470 \mathrm{mg} / \mathrm{l} \mathrm{COD}, 44 \mathrm{mg} / \mathrm{l} \mathrm{N}$ (27 Org$\mathrm{N}, 17 \mathrm{NH}_{4}{ }^{+}-\mathrm{N}$ ), $8 \mathrm{mg} / \mathrm{PO}_{4}{ }^{3-}-\mathrm{P}$, and $14 \mathrm{mg} / \mathrm{l} \mathrm{SO}_{4}{ }^{2-}$-S. Columns were gravity drained $3 \mathrm{~d}$ prior to each incubation and then again at the start of each incubation. Upon each emptying, columns were refilled from above with new wastewater. Sampling from all 16 columns occurred at days $0,1,3,6,9,14$ and 20 of each incubation and those sub-samples were analysed afterwards for the constituents.

\subsection{Model description and implementation}

Testing of the experimental data was performed by means of sensitivity analysis, parameter estimation and uncertainty analysis using AQUASIM computer program for the identification and simulation of aquatic systems developed by the Swiss Federal Institute for Environmental Science and Technology (Reichert, 1998). The academic software AQUASIM is extremely flexible in allowing the user to specify transformation processes and to perform simulations for a user-specified model. The mixed reactor compartment configuration in AQUASIM was used and defined by the volume of the wetland mesocosm, active variables, active processes, initial conditions and inputs. Parameters in AQUASIM were set as fixed, dynamic state, list or formula variables. Dynamic processes were used for the growth and decay rate of all bacteria groups as included in the CWM1. When 
implementing CWM1 in AQUASIM, the subsurface-flow wetland mesocosms are assumed to act as single continuous stirredtank reactor, supposing that all incoming constituents are evenly mixed throughout the entire mesocosm volume. This was corroborated by the fact that solution samples collected from 5 , 15 , and $30 \mathrm{~cm}$ depths during preliminary incubations showed no measurable vertical gradients for COD, dissolved organic carbon (DOC), or $\mathrm{SO}_{4}{ }^{2-}-\mathrm{S}$ (Allen et al., 2002). Default parameter values of CWM1 were adopted as published in Langergraber et al. (2009). Five plant processes (growth, physical degradation, decay, and oxygen leaching), physical re-aeration, as well as adsorption and desorption processes for COD and ammonium nitrogen, were also included as dynamic processes and are shown in Tables A1 and A2 in Appendix A.

Plant growth is modelled by means of 'relative growth rates' as there are many data available in the literature. Plant growth is not zero-order, but depends on ammonium and nitrate concentrations (Rousseau, 2005; Sanchez et al., 2004). Plant decay/senescence and physical degradation equations are based on the work of Wynn and Liehr (2001) and most importantly, plant material is no longer expressed as carbon but as COD, which is rather unusual but allows for a smooth integration with the COD-based microbial processes (Rousseau, 2005). Adsorption of COD is modelled by a chemical non-equilibrium adsorption of the slowly biodegradable particulate COD, with a linear adsorption isotherm following the work of Henrichs et al. (2007). The time dependency of adsorption is described by the concept of two-site sorption. Sorption is instantaneous on one part of the exchange sites whereas it is considered to be time-dependent on the remaining sites (Henrichs et al., 2007). Ammonium nitrogen sorption is described using a reversible Freundlich isotherm (McBride and Tanner, 1999). Temperature impact on microbiological process rates and on plant growth is modelled via the Arrhenius relationship.

To run the model, 19 inputs characterizing the influent (oxygen, COD fractions, $\mathrm{N}$ compounds, $\mathrm{S}$ compounds, and bacterial concentrations) and one input for water temperature are necessary. Fractionation of the influent wastewater COD was based on standard ratios given in the ASMs. Because the synthetic wastewater used in the experiment was mixed from sucrose, low molecular weight hydrolysed meat protein and other chemicals for nutrients, the section for particulate inert organic particles was set to zero, therefore the fractionation was modified as follows: $S_{-} A$ (acetate) $=10 \%, S \_$I (inert soluble COD) $=4 \%, X \_$(slowly biodegradable particulate COD $)=61 \%$ of the measured influent COD, $S_{-} F$ (fermentable, readily biodegradable soluble COD) $=25 \%$. $X_{-}$I (inert particulate COD) was set to zero.S_O (dissolved oxygen) in the influent was estimated to be the saturation concentration at the set temperature. $S_{-} \mathrm{NO}$ (nitrate and nitrite nitrogen), and $S_{-} \mathrm{H}_{2} \mathrm{~S}$ (dihydrogensulphide sulphur) were assumed not to be present in the influent.

\subsection{Sensitivity analysis}

A sensitivity analysis was carried out to recognize the most important parameters influencing the prediction of carbon, nitrogen and sulphur concentrations and the growth of different microbial biomass in CWM1. In AQUASIM, the sensitivity analysis feature enables calculation of linear sensitivity functions of arbitrary variables with respect to each of the parameters included in the analysis (Reichert, 1995). The sensitivity analysis results described in this study are those of the absolute-relative sensitivity function of AQUASIM (Eq. (1)) that computes the absolute change in a model output variable, $y$, for a $100 \%$ change in any parameter of interest, $p$. This makes quantitative comparisons of the different parameters on a common variable possible.

$\delta_{y, p}^{a, r}=p \frac{\partial y}{\partial p}$

The uncertainty is determined by using the error propagation formula (Eq. (2)), which is based on the linearized propagation of standard deviations of the parameters of interest, neglecting their correlation.

$\sigma_{y}=\sqrt{\sum_{i=1}^{m}\left(\frac{\partial y}{\partial p}\right)^{2} \sigma_{p_{i}}^{2}}$

where $p_{i}$ are the uncertain model parameters, $\sigma_{p_{i}}$ are their standard deviations, $y\left(p_{i}, \ldots, p_{m}\right)$ is the solution of the model equations for a given variable at a given location and time, and $\sigma_{y}$ is the approximate standard deviation of the model result. Identifiability of the model parameters was evaluated by use of parameter correlation matrix in AQUASIM.

\subsection{Model calibration}

Model parameters for CWM1 were adopted as described by Langergraber et al. (2009). The model requires the values of 51 kinetic parameters (16 first-order kinetic constants, 22 half-saturation coefficients and 13 inhibition constants) and 14 stoichiometric parameters (Llorens et al., 2011a). To optimize the parameter sets, the result of the sensitivity analysis was used to guide the selection and calibration of some kinetic coefficients. Data based on bulk measurements of $\mathrm{COD}, \mathrm{NH}_{4}{ }^{+}-\mathrm{N}$ and $\mathrm{SO}_{4}{ }^{2-}$ $\mathrm{S}$ at $12^{\circ} \mathrm{C}, 16^{\circ} \mathrm{C}, 20^{\circ} \mathrm{C}$ and $24^{\circ} \mathrm{C}$ from the unplanted (control) mesocosms were used for calibration of the microbial pathways. At this time the matured experimental units had been receiving synthetic wastewater for 17-20 months. To adjust parameter values, the parameter estimation tool of AQUASIM (secant and simplex algorithms) and trial-and-error approach was used. The measured data of incubation at $12{ }^{\circ} \mathrm{C}$ were used to estimate the initial bacterial concentration, the oxygen re-aeration coefficient, initial amount of sorbed ammonia and the COD adsorption parameters by simultaneous fitting of predicted $\mathrm{COD}, \mathrm{NH}_{4}{ }^{+}-\mathrm{N}$ and $\mathrm{SO}_{4}{ }^{2-}-\mathrm{S}$ profiles to experimental data. Then, the final concentrations for each of the bacterial group at the end of $20 \mathrm{~d}$ were inputted as initial concentrations for the following 3-d refreshing incubation. Finally, the concentrations at the end of the 3-d refreshing incubation were used as the input for the next batch, i.e. incubation temperature.

\subsection{Simulation and validation}

The simulations were conducted with data from planted mesocosms, at $12^{\circ} \mathrm{C}, 16^{\circ} \mathrm{C}, 20^{\circ} \mathrm{C}$ and $24^{\circ} \mathrm{C}$. Only the temperature, root oxygen loss parameter, ammonia and COD sorption parameters, and the initial bacterial concentration were changed in each simulation run. When estimating the initial bacterial concentrations, the lower limit values provided to AQUASIM were those obtained during calibration at the respective incubation temperatures with the unplanted mesocosms. For validation purposes, the model was run with a data set from a separate experimental campaign with higher sulphate concentrations in the mesocosms planted with Schoenoplectus (Stein et al., 2007). 
Table 1

Sensitivity ranking and mean values of the relative sensitivity function of predicted effluent concentrations.

\begin{tabular}{|c|c|c|c|c|c|}
\hline Relative sensitivity & S_A & $S_{-} \mathrm{F}$ & S_NH & $\mathrm{S}_{-} \mathrm{SO}_{4}$ & $X \_S$ \\
\hline$<1$ & & $K \_$SFB & $\mathrm{m}, Y_{-} \mathrm{H}, \mathrm{Kpl}, \mu_{-} \mathrm{H}$ & & $\mu \_\mathrm{H} 20, K \_\mathrm{H}, Y \_\mathrm{H}, b_{-} \mathrm{H}, K X$ \\
\hline$>1-10<$ & & $\begin{array}{l}Y_{-} \mathrm{H}, \mathrm{w}, \mu_{-} \mathrm{H}, k S_{-} \mathrm{COD}, K_{-} \mathrm{H}, \\
\mu_{-} \mathrm{FB}, Y_{-} \mathrm{FB},\end{array}$ & & $\begin{array}{l}Y \_ \text {ASRB }, \mu \text { ASRB }, \mu \_ \text {AMB, } \\
Y \_ \text {AMB }, K \_ \text {SOASRB }\end{array}$ & \\
\hline $10>$ & $\begin{array}{l}\mu_{\_} \mathrm{AMB}, Y_{-} \mathrm{AMB}, \mu_{-} \mathrm{H}, \\
K_{-} \mathrm{SAMB}, K_{-} \mathrm{OAMB}\end{array}$ & & & & $\mathrm{w}, k_{-} S_{-} \mathrm{COD}$ \\
\hline
\end{tabular}

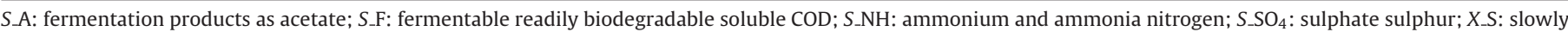
biodegradable particulate COD.

Table 2

Optimized parameter values and their correlation matrix.

\begin{tabular}{|c|c|c|c|c|c|c|c|}
\hline Parameters & Value in CWM1 (at $20^{\circ} \mathrm{C}$ ) & Value in this work (at $20^{\circ} \mathrm{C}$ ) & K_H & $\mu \_$ASRB & $\mu_{-} \mathrm{FB}$ & Y_AMB & $Y$ ASRB \\
\hline K_H & 3.00 & 0.58 & 1.00 & & & & \\
\hline$\mu_{-}$ASRB & 0.18 & 0.31 & -0.18 & 1.00 & & & \\
\hline$\mu_{-} \mathrm{FB}$ & 3.00 & 3.77 & 0.00 & -0.33 & 1.00 & & \\
\hline Y_AMB & 0.03 & 0.04 & -0.10 & -0.13 & -0.04 & 1.00 & \\
\hline Y_ASRB & 0.05 & 0.04 & -0.20 & 0.21 & -0.47 & -0.14 & 1.00 \\
\hline
\end{tabular}

Table 3

The initial bacterial concentrations obtained in the model calibration with the upper and lower bounds around the estimated bacteria concentration (mg COD/l).

\begin{tabular}{|c|c|c|c|c|c|c|c|}
\hline \multirow[t]{2}{*}{ Temp $\left({ }^{\circ} \mathrm{C}\right)$} & \multicolumn{6}{|c|}{ Bacteria group } & \multirow[t]{2}{*}{ Total conc. } \\
\hline & X_Aini & X_AMBini & X_ASRBini & $X \_$FBini & $X \_$Hini & X_SOBini & \\
\hline 12 & 67.1 & 58.8 & 14.4 & 1.2 & 363.3 & 2.9 & 507.6 \\
\hline 16 & 79.4 & 58.3 & 6.7 & 55.4 & 138.0 & 2.1 & 339.8 \\
\hline 20 & 37.9 & 71.3 & 7.0 & 37.0 & 83.7 & 2.7 & 239.6 \\
\hline 24 & 35.0 & 95.3 & 5.0 & 50.3 & 45.0 & 1.0 & 231.6 \\
\hline$\%$ upper bound & 8.6 & 33.3 & 3.3 & 18.2 & 10.0 & 21.2 & \\
\hline$\%$ lower bound & 8.6 & 39.9 & 3.3 & 18.6 & 10.0 & 21.2 & \\
\hline
\end{tabular}

\section{Results}

\subsection{Sensitivity}

The biokinetic parameters (kinetic rate constants, stoichiometric and composition parameters) and initial conditions were directly selected for sensitivity analysis. A sensitivity ranking of the most sensitive parameters according to the average absolute value of the "absolute relative" sensitivity function in AQUASIM is shown in Table 1. According to Table 1, the yield coefficients for methanogenic, sulphate reducing, fermenting and heterotrophic bacteria, saturation/inhibition coefficients for oxygen, sulphate, acetate, fermentable COD and hydrolysis, plant growth rate constant, rate constant for lysis of heterotrophic bacteria and the COD sorption coefficients are among the most sensitive and distinct parameters affecting the predicted concentrations.

\subsection{Model calibration, identifiability and uncertainty}

Default parameter values were implemented as proposed for CWM1 in Langergraber et al. (2009). Only 5 parameters needed to be adjusted during calibration as shown in Table 2 . The correlation matrix (Table 2) shows minimal linear dependency between calibrated parameters, which increases their identifiability within the range of available data. It was found necessary to adopt low value for hydrolysis rate constant (through parameter estimation in AQUASIM) to be able to satisfactorily match the measured COD and $\mathrm{NH}_{4}{ }^{+}$data. The remarkable difference between the hydrolysis rate constant value $K_{-} H$ in CWM1 and this work suggest low hydrolysis activity in the wetland mesocosm, which is conceivable considering that the constituents of the synthetic wastewater were mainly of low molecular weight. The estimated bacterial concentrations obtained during calibration at the different incubation temperatures, together with the percentage upper and lower bounds around the estimated bacteria concentrations are given in Table 3. It was found that acetotrophic methanogenic bacteria (X_AMB), fermenting bacteria (X_FB) and heterotrophic bacteria $\left(X_{-} H\right)$ become the most abundant organisms in the control mesocosm. The percentage concentration bounds suggest a low to medium uncertainty for the estimated initial bacterial concentrations. The correlation matrix (not shown) indicated a minimal linear correlation among the estimated initial bacteria concentration values, except for the heterotrophic and the acetotrophic methanogenic bacteria that had a significant negative correlation of 0.84 . The goodness of fit between the observed and simulated concentrations in the calibrated model (control mesocosms) was evaluated with the coefficient of determination $\left(R^{2}\right)$. The $R^{2}$ values for COD (0.97-0.99), $\mathrm{NH}_{4}{ }^{+}-\mathrm{N}(0.85-0.97)$ and $\mathrm{SO}_{4}{ }^{2-}-\mathrm{S}(0.71-0.93)$

Table 4

Root oxygen transfer rates in the planted wetland mesocosms.

\begin{tabular}{|c|c|c|c|c|}
\hline & \multicolumn{4}{|c|}{ Root oxygen transfer (as $\mathrm{g}_{2}$ per $\mathrm{m}^{2}$ wetland area $\mathrm{d}^{-1}$ ) } \\
\hline & $12^{\circ} \mathrm{C}$ & $16^{\circ} \mathrm{C}$ & $20^{\circ} \mathrm{C}$ & $24^{\circ} \mathrm{C}$ \\
\hline Carex & 1.91 & 0.47 & $2.13 \mathrm{E}-05$ & $2.65 \mathrm{E}-05$ \\
\hline Schoenoplectus & 0.94 & $2.60 \mathrm{E}-04$ & $2.13 \mathrm{E}-05$ & $2.66 \mathrm{E}-05$ \\
\hline Typha & 0.45 & $3.68 \mathrm{E}-02$ & $5.38 \mathrm{E}-03$ & $2.60 \mathrm{E}-04$ \\
\hline
\end{tabular}


Table 5

Initial bacterial concentrations ( $\mathrm{mg} \mathrm{COD} / \mathrm{l}$ ) values of planted wetland mesocosms defined during simulations.

\begin{tabular}{|c|c|c|c|c|c|c|c|c|}
\hline \multirow[t]{2}{*}{ Set-up } & \multirow[t]{2}{*}{ Temp $\left({ }^{\circ} \mathrm{C}\right)$} & \multicolumn{6}{|c|}{ Bacteria group } & \multirow[t]{2}{*}{ Total conc. (mg COD/l) } \\
\hline & & $X \_$Aini & X_AMBini & X_ASRBini & X_FBini & X_Hini & X_SOBini & \\
\hline \multirow[t]{4}{*}{ Carex } & 12 & 52.6 & 202.0 & 15.3 & 15.2 & 296.6 & 30.4 & 612.2 \\
\hline & 16 & 79.5 & 185.8 & 6.7 & 56.5 & 138.0 & 17.0 & 483.5 \\
\hline & 20 & 38.4 & 135.0 & 6.7 & 63.4 & 45.3 & 4.4 & 293.1 \\
\hline & 24 & 35.0 & 95.3 & 5.0 & 50.3 & 45.0 & 1.0 & 231.6 \\
\hline \multirow[t]{4}{*}{ Schoenoplectus } & 12 & 53.4 & 167.1 & 21.0 & 11.3 & 297.7 & 38.4 & 588.9 \\
\hline & 16 & 79.4 & 131.1 & 6.7 & 55.4 & 138.0 & 9.0 & 419.6 \\
\hline & 20 & 38.4 & 94.4 & 6.7 & 55.4 & 48.3 & 16.4 & 259.6 \\
\hline & 24 & 10.0 & 110.1 & 6.7 & 55.4 & 68.2 & 10.8 & 261.2 \\
\hline \multirow[t]{4}{*}{ Typha } & 12 & 52.8 & 102.6 & 16.7 & 10.2 & 297.1 & 82.3 & 561.7 \\
\hline & 16 & 79.4 & 90.7 & 7.4 & 55.4 & 155.8 & 17.4 & 406.1 \\
\hline & 20 & 42.0 & 103.0 & 6.7 & 43.8 & 86.4 & 2.4 & 284.2 \\
\hline & 24 & 10.3 & 61.4 & 5.1 & 50.6 & 45.7 & 2.9 & 267.0 \\
\hline
\end{tabular}

indicate that the simulated data fit well with the observed data after calibration.

\subsection{Simulations results}

Root oxygen transfer rates obtained from the model simulation are listed in Table 4. Oxygen transfer through diffusion or physical re-aeration were found to be at a low rate, calibrated at $0.05 \mathrm{~g} \mathrm{~m}^{-2} \mathrm{~d}^{-1}$ at $12{ }^{\circ} \mathrm{C}$ and $0.09 \mathrm{~g} \mathrm{~m}^{-2} \mathrm{~d}^{-1}$ at $24{ }^{\circ} \mathrm{C}$ in the control mesocosm. According to the simulations, appreciable plant root oxygen release occurred at $12^{\circ} \mathrm{C}$ at rates of $1.91,0.94$, and $0.45 \mathrm{~g} \mathrm{~m}^{-2} \mathrm{~d}^{-1}$ in the Carex, Schoenoplectus and Typha mesocosms, respectively. This can be explained by the fact that availability of oxygen is temperature dependent, since solubility of oxygen increases with decreasing temperature, which influences concentration gradients and internal transport of oxygen in the plants by molecular diffusion. Indeed besides the mesocosm planted with Carex at $16^{\circ} \mathrm{C}$, no meaningful root oxygen leaching was obtained for all the tests in the planted columns at $16^{\circ} \mathrm{C}, 20^{\circ} \mathrm{C}$ and $24^{\circ} \mathrm{C}$. The rate of root oxygen release decreased with an increase in temperature.

Model simulations of COD, $\mathrm{SO}_{4}{ }^{2-}-\mathrm{S}$ and $\mathrm{NH}_{4}{ }^{+}-\mathrm{N}$ were compared to the observed data to demonstrate the degree of agreement and to discuss the most important phenomena visible in the data. Figs. 2-4 show the simulation profiles of $\mathrm{COD}, \mathrm{NH}_{4}{ }^{+}-\mathrm{N}$ and $\mathrm{SO}_{4}{ }^{2-}-\mathrm{S}$ in the unplanted and planted wetland mesocosms at the various incubation temperatures. The simulation results demonstrated that the model was able to describe the general trend of COD, ammonium and sulphate removal in both planted and unplanted (control) mesocosms throughout the experimental temperature range of $12-24^{\circ} \mathrm{C}$. The estimated bacterial concentrations obtained during the simulations at the selected incubation temperatures, are given in Table 5. It was found that acetotrophic methanogenic bacteria $\left(X \_\right.$AMB $)$, fermenting bacteria $\left(X_{-} \mathrm{FB}\right)$ and heterotrophic bacteria $\left(X_{-} H\right)$ become the most abundant organisms in the simulated wetlands (planted mesocosms).

\subsection{1. $C O D$}

Analyses of COD degradation pathways are shown in Fig. 1. The rates predicted by the model show that anaerobic degradation plays a major role on the COD removal both in the planted and unplanted mesocosm. Removal of COD through the aerobic pathway varied between 14.2 and $43.5 \%$, only $0-0.2 \%$ was removed by anoxic reactions (denitrification), while $45.6-80.4 \%$ of the COD removal was via the anaerobic pathway. The simulated residual was found to lie between 4.9 and $26.0 \%$. Larger removal of COD by aerobic processes ( $>30 \%$ ) occurred at $12^{\circ} \mathrm{C}$ and $16^{\circ} \mathrm{C}$ in the Carex and Schoenoplectus planted wetlands coinciding with higher root oxygen transfer rates as deduced in the simulation.

Fig. 2 compares simulated (with and without adsorption) and measured COD concentrations for both planted and unplanted mesocosms. The graphs show that COD predictions with adsorption on the gravel media were generally in good agreement with the measured data. However, in some instances there are moderate over/under estimations which seem to indicate that the mathematical model has a much faster/slower COD removal rate than experimental units. The difference between measured COD removal and simulated COD removal excluding adsorption is generally much larger than when adsorption is considered. This
Control

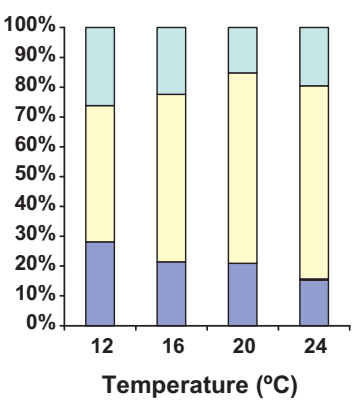

Carex

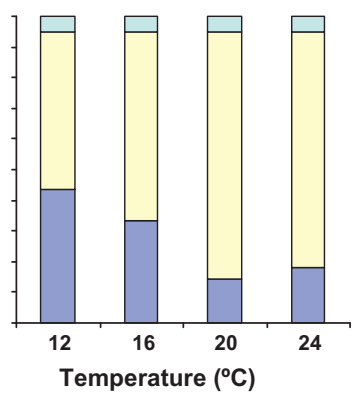

Schoenoplectus

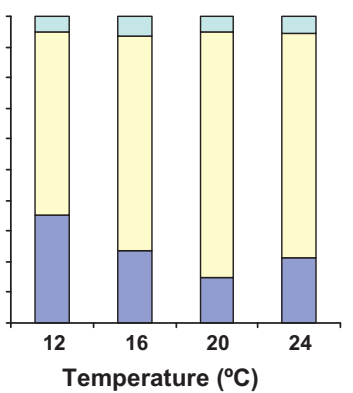

Typha

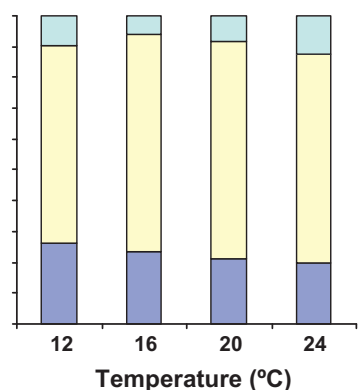

Aerobic $\square$ Anaerobic $\square$ Residual

Anoxic

Fig. 1. Percentage contribution to COD degradation by aerobic, anoxic and anaerobic pathways from model simulations. 

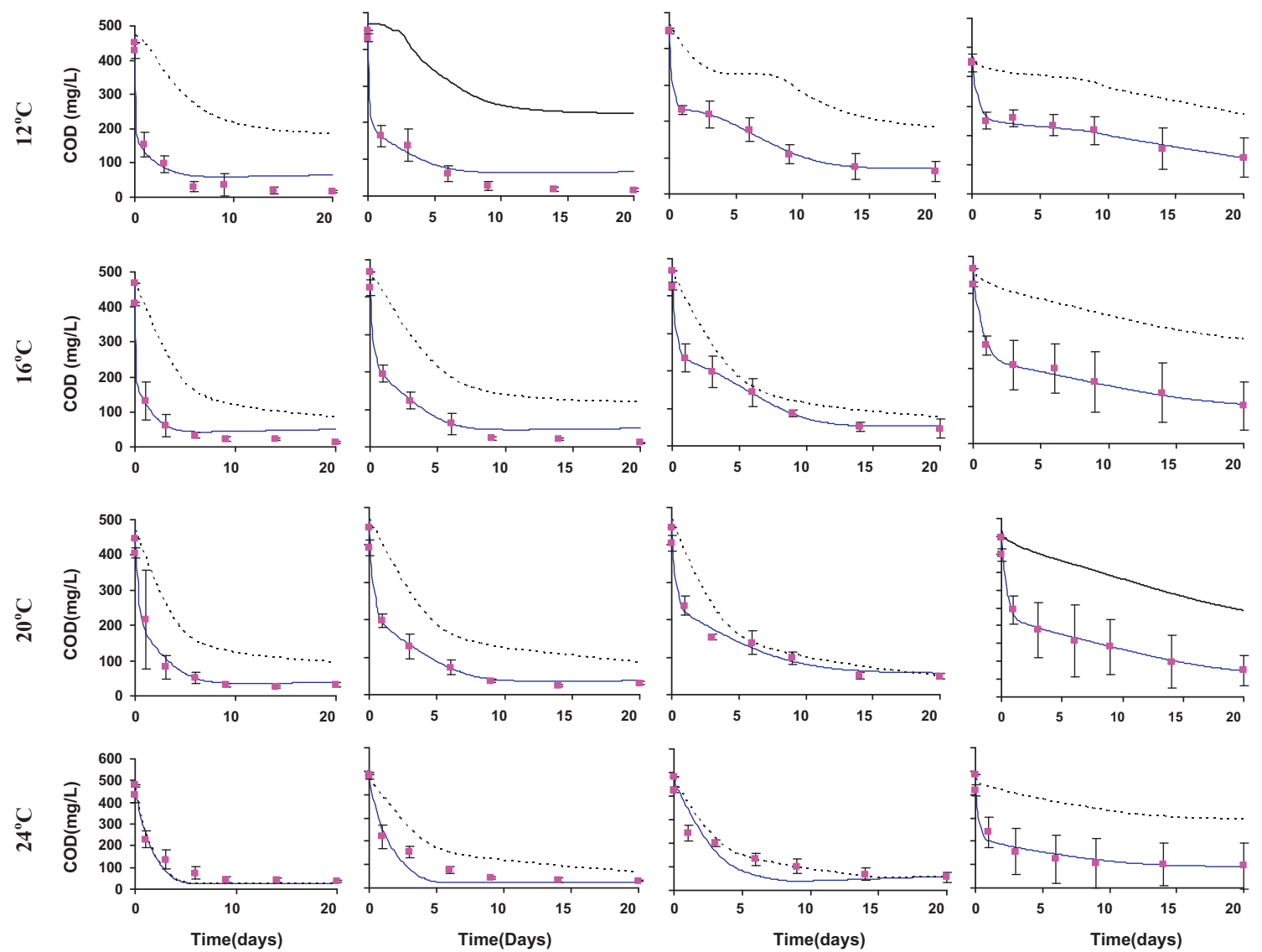

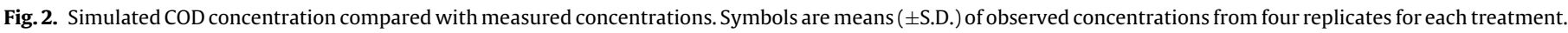
Solid lines are CWM1-AQUASIM simulation curves and dotted lines are CWM1-AQUASIM simulations without sorption.

difference decreases with increase in the incubation temperature in the planted columns, however this trend is not observed in the simulated results of the unplanted columns. The adsorption pattern tends to follow that of the simulated bacterial concentrations. In practice it is often assumed that COD is adsorbed onto the biofilm covering the substrate from where it is further processed. Table 6 shows the coefficient of determination values $\left(R^{2}\right)$ for the goodness of fit with and without adsorption processes during the simulation.

\subsection{2. $\mathrm{SO}_{4}{ }^{2-}-\mathrm{S}$}

Measured and simulated $\mathrm{SO}_{4}{ }^{2-}-\mathrm{S}$ concentrations are compared in Fig. 3. Model $\mathrm{SO}_{4}{ }^{2-}-\mathrm{S}$ predictions generally agree well with the measured data, except for some overestimation at the earlier days of incubation in some cases. The observed and simulated $\mathrm{SO}_{4}{ }^{2-}-\mathrm{S}$ removal profiles have got a pattern similar to those of COD, i.e. a high removal rate within the first $3 \mathrm{~d}$ suggesting that sulphate was used as an electron acceptor for organic carbon removal.

\subsection{3. $\mathrm{NH}_{4}^{+}-\mathrm{N}$}

Fig. 4 shows the simulated $\mathrm{NH}_{4}{ }^{+}-\mathrm{N}$ concentration compared with the measured $\mathrm{NH}_{4}{ }^{+}-\mathrm{N}$ concentration in the wetland mesocosms. The observed rapid initial decline of $\mathrm{NH}_{4}{ }^{+}-\mathrm{N}$ in planted columns and increase of $\mathrm{NH}_{4}{ }^{+}-\mathrm{N}$ in unplanted columns are predicted well, and those can be achieved only with a sorption process included in the model. To do so, the process of reversible sorption of ammonium onto the gravel was set to be active and an initial concentration of sorbed ammonium was also fitted. According to the simulations, the initial sorbed ammonium (X_NHini) concentration was found to be almost the same at different incubations for a specific column as shown in Table 7. This suggests that the full sorption potential of the gravel would be available after every $3 \mathrm{~d}$ refresh incubation, implying the ammonia adsorbed on the gravel was partly removed during the short period of draining and refilling of the wastewater between batches when the gravel was exposed to air. The variability of $X$ NHini between the mesocosms is explicable

Table 6

$R^{2}$ for the goodness of fit for COD with (active) and without (inactive) COD adsorption processes.

\begin{tabular}{|c|c|c|c|c|c|c|c|c|}
\hline \multirow[t]{2}{*}{$\operatorname{Temp}\left({ }^{\circ} \mathrm{C}\right)$} & \multicolumn{2}{|l|}{ Control } & \multicolumn{2}{|l|}{ Carex } & \multicolumn{2}{|c|}{ Schoenoplectus } & \multicolumn{2}{|l|}{ Typha } \\
\hline & Active & Inactive & Active & Inactive & Active & Inactive & Active & Inactive \\
\hline 12 & 0.984 & 0.781 & 0.997 & 0.671 & 0.993 & 0.645 & 0.932 & 0.843 \\
\hline 16 & 0.995 & 0.813 & 0.994 & 0.713 & 0.979 & 0.843 & 0.893 & 0.892 \\
\hline 20 & 0.996 & 0.769 & 0.997 & 0.869 & 0.976 & 0.857 & 0.907 & 0.898 \\
\hline 24 & 0.979 & 0.729 & 0.975 & 0.975 & 0.961 & 0.882 & 0.893 & 0.905 \\
\hline
\end{tabular}



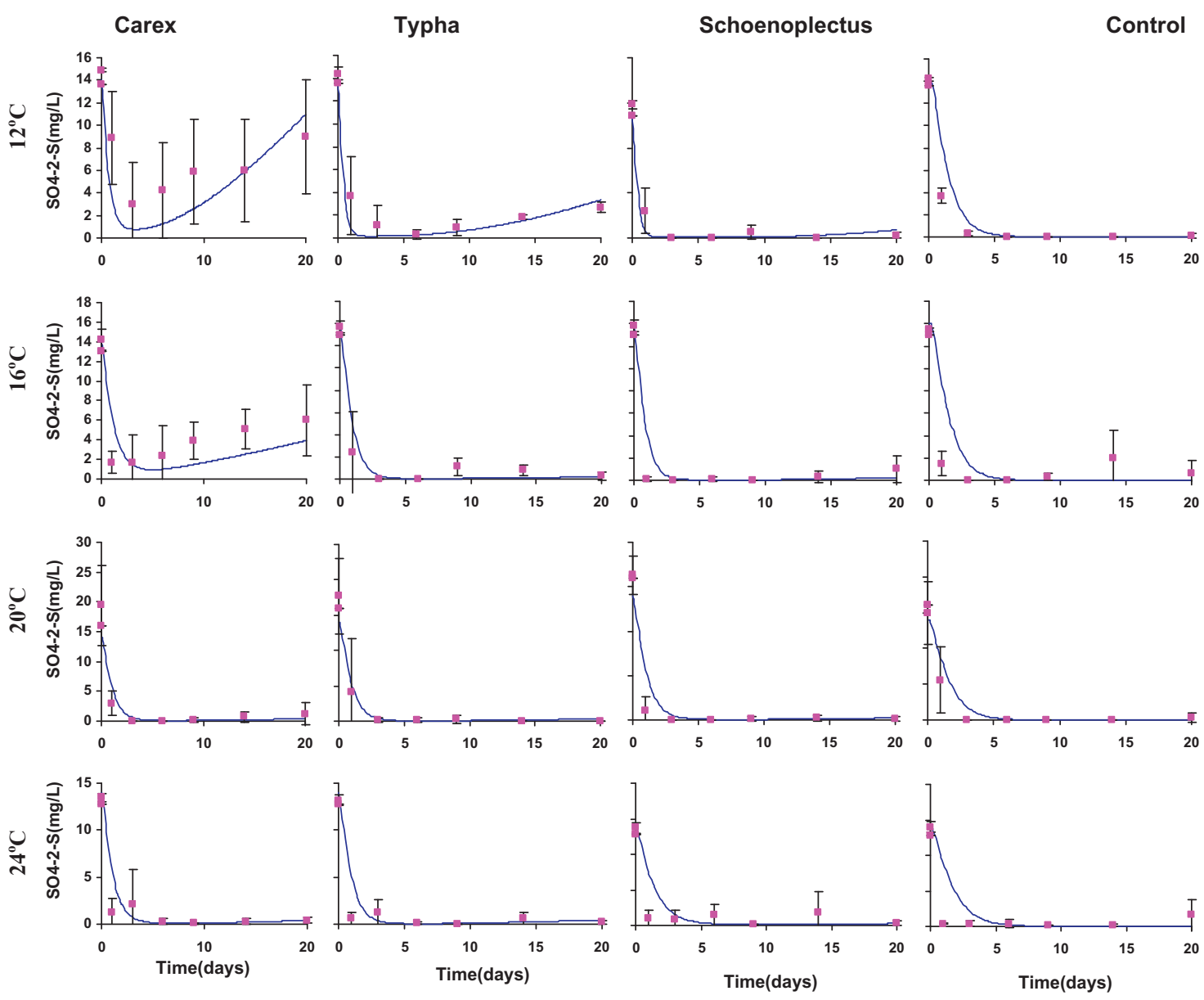

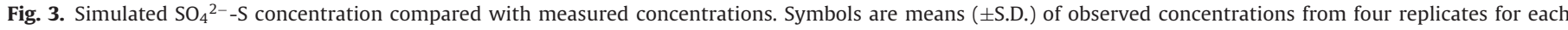
treatment. Solid lines are CWM1-AQUASIM simulation curves.

only as a combination of the root oxygen release potential of individual plant species and the below ground biomass characteristics, i.e. root density, depth and thickness. The contribution by nitrification, plant uptake and the sorption processes to the observed decline in $\mathrm{NH}_{4}{ }^{+}-\mathrm{N}$ concentration in the planted mesocosms was computed as listed in Table 8.

\subsubsection{Validation}

For validation purposes, the model was run with a data set from a separate experimental campaign utilizing mesocosms planted with Schoenoplectus and higher sulphate concentrations (69.01 and $74.79 \mathrm{mg} / \mathrm{l} \mathrm{SO}_{4}{ }^{2-}-\mathrm{S}$ ) mesocosm (Stein et al., 2007). The simulated data fit reasonably well (Fig. 5) with $R^{2}$ values of $(0.97,0.92)$ and $(0.64,0.83)$ for COD and $\mathrm{SO}_{4}{ }^{2-}-\mathrm{S}$ at $14{ }^{\circ} \mathrm{C}$ and $24^{\circ} \mathrm{C}$, respectively.

\section{Discussion}

Mechanistic models have become promising tools for understanding the parallel processes and interactions between water,

Table 7

Initial concentration of adsorbed ammonia ( $\mathrm{g} / \mathrm{kg}$ gravel).

\begin{tabular}{lllll}
\hline Temp $\left({ }^{\circ} \mathrm{C}\right)$ & Control & Carex & Schoenoplectus & Typha \\
\hline 12 & 13.9 & 3.2 & 5.0 & 6.0 \\
16 & 14.0 & 3.0 & 5.4 & 5.8 \\
20 & 14.3 & 3.0 & 6.0 & 6.0 \\
24 & 13.8 & 3.0 & 6.7 & 6.0 \\
\hline
\end{tabular}

granular media, macrophytes, litter, detritus and microorganisms occurring in constructed wetlands. The goal of this work was to implement in within AQUASIM software the reaction model CWM1 and to yield simulation results comparable to concentrations actually measured for a constructed wetland mesocosm system operated in batch mode. The implementation of CWM1 with adsorption, physical oxygen re-aeration and plant processes into AQUASIM was done freely. This requirement of freedom in specifying a model in simulation software is essential to eliminate barriers for potential model users, while producing realistic simulation results (Meysman et al., 2003). Considering the large number

Table 8

Percentage contribution to the observed decline in $\mathrm{NH}_{4}{ }^{+}-\mathrm{N}$ concentration by nitrification, plant uptake and sorption processes.

\begin{tabular}{lllll}
\hline Set-up & Temp $\left({ }^{\circ} \mathrm{C}\right)$ & Nitrification & Plant uptake & Sorption \\
\hline \multirow{4}{*}{ Carex } & 12 & 2.0 & 20.5 & 70.2 \\
& 16 & 1.0 & 4.3 & 89.1 \\
& 20 & 0.1 & 4.0 & 89.8 \\
\multirow{5}{*}{ Schoenoplectus } & 24 & 0.0 & 4.0 & 92.0 \\
& 12 & 0.1 & 30.0 & 55.0 \\
& 16 & 0.7 & 0.5 & 81.0 \\
\multirow{4}{*}{ Typha } & 20 & 0.1 & 0.3 & 74.7 \\
& 24 & 0.0 & 0.1 & 82.0 \\
& 12 & 0.0 & 10.4 & 69.6 \\
& 16 & 0.0 & 1.5 & 75.0 \\
& 20 & 0.0 & 0.4 & 77.0 \\
\hline
\end{tabular}



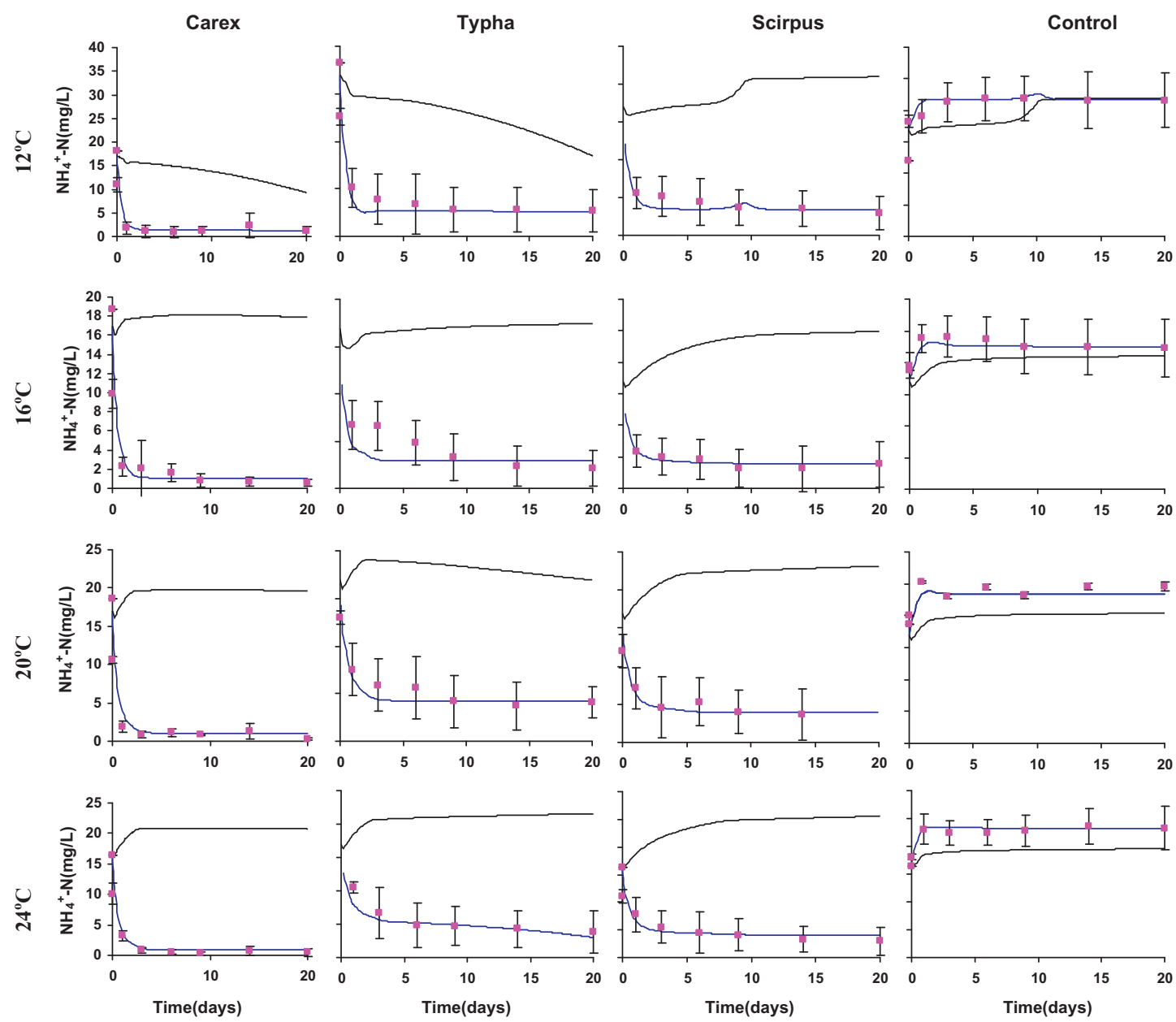

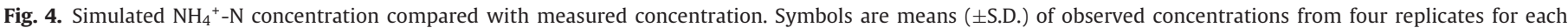
treatment. Solid lines are CWM1-AQUASIM simulation curves and dotted lines are CWM1-AQUASIM simulations without sorption.

of parameters in CWM1 defining different microbial pathways, colinearity prevented a high identifiability for some parameters of the six microbial groups considered in the model. Deviations between predicted and experimental data especially at low temperatures, may be caused by the non-identification of some CWM1 bacteria groups due to a compensation effect, underlining the need for higher resolution experimental data, for example a narrow difference between incubation temperatures at lower temperatures and/or sampling time steps. Further, the use of synthetic wastewater as was the case in this study may give rise to uncertainty in wastewater characterization, i.e. fractionation while following the standard ASM ratios. Changes in the feed solution configuration
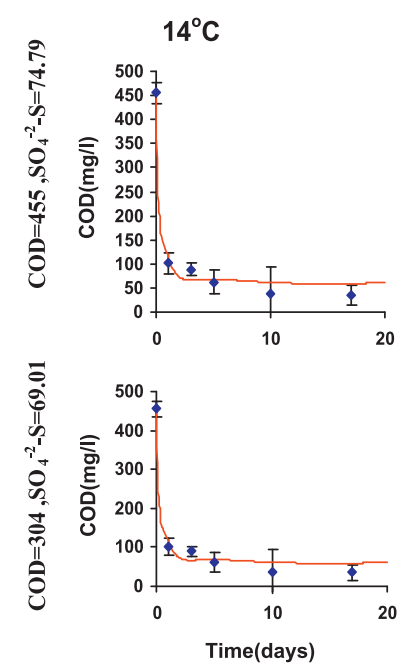

$24^{\circ} \mathrm{C}$

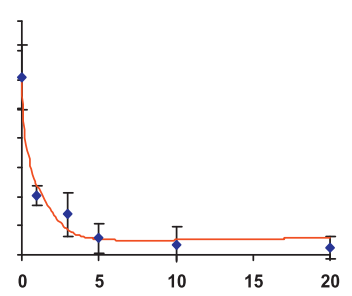

$14^{\circ} \mathrm{C}$
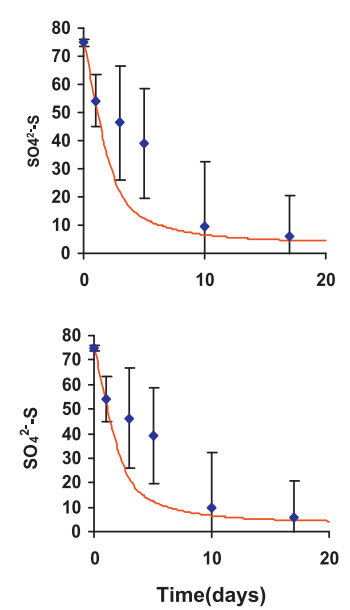

$24^{\circ} \mathrm{C}$
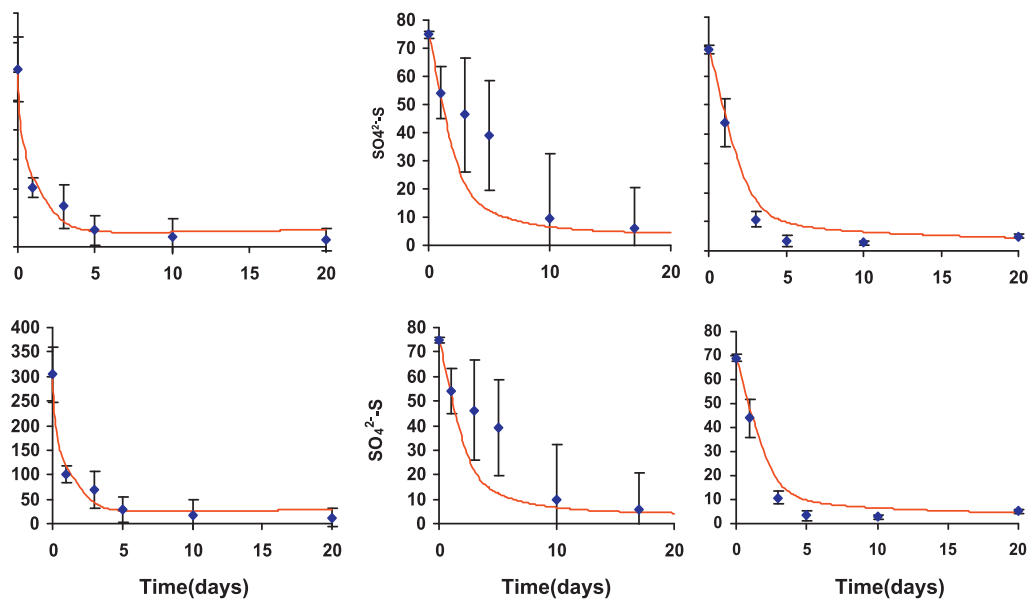

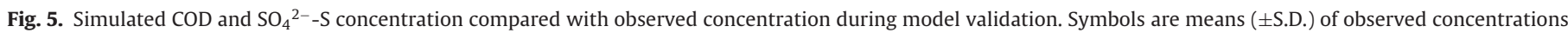
from four replicates for each treatment. Solid lines are CWM1-AQUASIM simulation curves. 
Table 9

Plant oxygen release reported by various researchers.

\begin{tabular}{|c|c|c|c|}
\hline Plant & Amount of oxygen release by plant & Remarks & Reference \\
\hline Schoenoplectus & $\begin{array}{l}0.00104-0.00443\left(\mathrm{~g} \mathrm{O}_{2} \mathrm{~m}^{-2} \mathrm{~d}^{-1}\right) \\
0.8\left(\mathrm{~g} \mathrm{O}_{2} \mathrm{~m}^{-2} \mathrm{~d}^{-1}\right)\end{array}$ & $\begin{array}{l}\text { Field and lab study } \\
\text { Based on } \mathrm{NH}_{4}{ }^{2-}-\mathrm{N} \text { removal }\end{array}$ & $\begin{array}{l}\text { Bezbaruah and Zhang } \\
\text { (2005) }\end{array}$ \\
\hline Typha & $0.00384-0.0064\left(\mathrm{~g} \mathrm{O}_{2}\right.$ dry weight $\left.^{-1} \mathrm{~h}^{-1}\right)$ & Lab study & Jespersen et al. (1998) \\
\hline Carex & $0.64 \pm 0.45$ (at $\left.4^{\circ} \mathrm{C}\right)$ to $0.67 \pm 0.163\left(24^{\circ} \mathrm{C}\right)\left(\mathrm{mg} \mathrm{O}_{2}\right.$ plant $\left.^{-1} \mathrm{~d}^{-1}\right)$ & Microcosm & Taylor (2009) \\
\hline
\end{tabular}

would affect the predicted bacterial concentration and consequently the relative contribution of microbial reactions to organic matter removal. Nevertheless the constituents of the synthetic wastewater were both constant and known making the application to the model easier.

\subsection{Oxygen transfer}

The extension of CWM1 to include physical re-aeration and root oxygen release from macrophytes among other processes has been recommended for the formulation of a full model for constructed wetlands (Langergraber et al., 2009). As oxygen consumption is very rapid in wastewater treatment technologies, and hence difficult to determine by direct measurement (Tyroller et al., 2010), indirect estimation of the oxygen transfer rate by both physical re-aeration and plant root oxygen release was attempted through inverse modelling. Direct oxygen transfer from air to water in the mesocosm is modelled in relation to an oxygen deficit as is usually considered in running waters. Low values obtained for the physical re-aeration rate could perhaps be explained by the fact that the air-water interface was subsurface and static, and neither the liquid nor gaseous phases were turbulently well mixed. However atmospheric oxygen diffusion is affected by a range of atmospheric conditions including temperature and relative humidity and wide range of oxygen diffusion, $0-28.6 \mathrm{~g} / \mathrm{m}^{2} \mathrm{~d}$ has been reported using different techniques and configurations of constructed wetlands (Wu et al., 2001).

Root oxygen release is a continuing subject of debate in subsurface flow CW research (Ojeda et al., 2008). Root oxygen release processes are said to depend on among others factors, plant species, plant biomass and season (Brix, 1999; Caffrey and Kemp, 1991), which could explain the difference in the oxygen release rates obtained between the three plant species and at the different incubation temperatures. Considering that the mesocosms had the same electron acceptor availability, the simulated root oxygen transfer at the lower temperatures potentially explains the observed greater COD removal in the Carex and Schoenopletus mesocosms but the absence of this temperature response in the Typha and the control mesocosms (Allen et al., 2002). While the root oxygen release rates determined this way (i.e. estimation by fitting measured data) are comparable to values obtained by other methodologies (Table 9), it is generally recognized that wetland plants do not generate enough oxygen to fully remove pollutants from wastewater (Brisson and Chazarenc, 2009; Brix, 1997; Tanner, 2001). Recent studies have shown that aerobic respiration plays only a minor role to the overall organic matter decomposition while anaerobic processes generally would play a major role in subsurface flow CWs with minimum oxygen renewal capacities (Llorens et al., 2011b; Ström et al., 2005). The depletion of $\mathrm{SO}_{4}{ }^{2-} \mathrm{S}$ in both the simulation and measurements as shown in Fig. 3 also imply an insufficient oxygen supply to the columns because sulphate is reduced by the acetotrophic sulphate reducing bacteria only after oxygen and other more thermodynamically favourable electron acceptors have been depleted (Allen et al., 2002; Wiessner et al., 2005). Thus subsurface constructed wetlands with minimal oxygen renewal capacities such as horizontal subsurface flow wetlands should be designed as an anaerobic or an aerobic-anaerobic hybrid system rather than as an aerobic system (Bezbaruah and Zhang, 2005).

\subsection{Influence of plants and temperature on bacterial biomass}

The removal of wastewater constituents in CWM1 is associated with a specific microbial functional group, reflecting a fundamental characteristic of wastewater treatment facilities (including wetlands) where their functioning relies heavily on the metabolism of microorganisms contained within sludge or biofilm (Ragusa et al., 2004). Nevertheless microbial activity in constructed wetlands is still largely based on assumption and circumstantial evidence as there is a lack of effective indicators of biofilm function and health in water treatment systems (Faulwetter et al., 2009; Ragusa et al. 2004). By running the model, estimates of the initial concentration of the six bacteria group considered in CWM1 were made at different incubation temperatures. The sensitivity ranking (not shown) demonstrated that the initial bacteria concentration as boundary condition was significantly influential on the model processes. The estimated values for initial bacteria concentration (found to have a low to moderate uncertainty) in the modelled batch systems are comparable to and within the range of those determined from simulation studies of subsurface constructed wetlands with continuous flow, e.g. Rousseau (2005) and Llorens et al. (2011a,b). From the simulations, the planted mesocosm required a higher total bacteria concentration, compared with the unplanted controls, suggesting that incorporation of plant roots into substrate of constructed wetlands enhances microbial populations related to the transformation and degradation of pollutants in constructed wetlands.

The model agreed with the assumption that plants can affect bacterial density and activities in constructed wetland (Gagnon et al., 2007), with vegetation having a positive effect on the treatment efficiency for organics and nutrients such as nitrogen and phosphorus. Besides root surface area for microbial growth, it has been suggested that plant rhizosphere provides a source of carbon compounds through root exudates and a micro-environment via root oxygen release that can affect microbial species composition and diversity (Vymazal, 2011).

Temperature impact on microbiological process rates and on plant growth is expressed through growth and decay rates, as well as other kinetic parameters in this model. It is generally accepted that most bacterial activity will decrease at lower temperatures, which may in turn influence the wetland performance. However, both the measured and simulated results in this work demonstrate that, the resultant effect on the wetland performance may not necessarily be related to temperature. It was seen by running the model that the abundance of some bacterial function groups, such as heterotrophs is generally higher at lower temperatures compared to high temperatures. Low temperatures may cause population shifts by altering growth rates of the individual species in different ways changing the competitive situation between species (Kotsyurbenko, 2005; Lew et al., 2004). The observed trend is in agreement with the results of Honda and Matsumoto (1983), who observed the growth capacity of a microbial film in a model trickling filter to increase as temperature fell. This is due to the autolysis coefficient which becomes lower at low temperatures (Honda and Matsumoto, 1983). On the other hand calibration 
simulations indicated that methanogenic bacterial concentrations increased with temperature, apparently because in the model they are not limited by a substrate such as sulphate that was removed rapidly within the first $3 \mathrm{~d}$ of incubation. In this case sulphate deficiency leads to minimal utilization of acetate as an electron donor for the sulphate reducing bacteria, and acetate is mainly used by methanogenic bacteria (Kalyuzhnyi and Fedorovich, 1998).

\subsection{COD anaerobic degradation and sorption}

Anaerobic transformation and degradation of COD was the dominant process (Fig. 1) in agreement with other findings on microorganism activity in subsurface flow constructed wetlands (García et al., 2005; Imfeld et al., 2009; Llorens et al., 2011a). Considering that the redox potentials and sulphate concentrations were high immediately after filling the columns with fresh wastewater and generally decreased rapidly within $24 \mathrm{~h}$ (Allen et al., 2002), organic matter degradation was likely achieved by anaerobic bacteria (Baptista et al., 2003; García et al., 2005). The widespread occurrence of anaerobic reactions in CWs has also been shown by Llorens et al. (2011b) with methanogenesis contributing 58-73\% to the COD removal.

The greatest difference in performance (for COD) among the mesocosms was at lower temperature as reported in Stein and Hook (2005). At low temperatures the planted columns seem to have an enhanced capacity for COD adsorption coupled to a relatively active root oxygen release rate. Some previous studies have indicated that the measured behaviour of wetland systems can only be modelled if COD adsorption is considered as an additional process (Henrichs et al., 2007). The model simulations of the current study indicate that the impact of adsorption-desorption processes is more significant at lower temperatures $\left(12^{\circ} \mathrm{C}\right.$ and $\left.16^{\circ} \mathrm{C}\right)$ especially in the planted mesocosms, and that at these temperatures biochemical processes alone could not account for the observed COD removal (Fig. 2). This result underlines the importance of a COD adsorption-desorption process in batch operated constructed wetlands. Contribution by plant physical degradation and decay to increase of organic matter in the planted mesocosms was found to be insignificant within the $20 \mathrm{~d}$ simulation period.

\section{4. $\mathrm{NH}_{4}{ }^{+}-\mathrm{N}$ removal mechanisms}

Nitrogen transformation and removal mechanisms in constructed wetlands include mineralization (ammonification), ammonia volatilization, nitrification, denitrification, plant and microbial uptake, nitrogen fixation, nitrate reduction, anaerobic ammonia oxidation (ANAMMOX), adsorption, desorption, burial and leaching (Vymazal, 2007). In this study the estimated contribution by plant uptake to the decline of $\mathrm{NH}_{4}{ }^{+}-\mathrm{N}$ concentration ranged between $0.1 \%$ and $30 \%$ (Table 8 ). Plant uptake of nitrogen is typically seen as a less significant nitrogen removal mechanism (Tunçsiper, 2009). Contribution by nitrification was also found to be low. This could have been influenced by the ammonia held and released by sorption process and the fact that available oxygen in the wastewater is quickly utilized by heterotrophic bacteria for the metabolism of organic carbon. This can also be seen from the results of the sensitivity analysis (Table 1 ) that shows sorption and heterotrophic bacteria rather than autotrophic bacteria growth rate and yield parameters as having the largest impact on simulated $\mathrm{NH}_{4}{ }^{+}-\mathrm{N}$ concentration. A high ammonia reduction rate in constructed wetlands with minimum oxygen renewal capacities is often less likely because the amount of oxygen available for bacterial oxidation of ammonium, or nitrification, is usually limited ( $\mathrm{Wu}$ et al., 2001). The simulation highlights the significance of the sorption process for ammonium fate in the batch mesocosms, as also discussed in McBride and Tanner (1999). Effluent concentration of $\mathrm{NH}_{4}{ }^{+}-\mathrm{N}$ matched the measured concentration well only with the sorption process active in the simulation. This applied for the controls (unplanted columns) as well where an increase in $\mathrm{NH}_{4}{ }^{+}-\mathrm{N}$ due to organic nitrogen ammonification was predicted well.

\subsection{Model advantages and limitations}

The CWM1-AQUASIM (with adsorption and plant processes implemented) positively captured the influence of temperature, and the presence and species of macrophyte. The model elucidates the performance attributes and factors that describe the observed trends in $\mathrm{COD}, \mathrm{SO}_{4}{ }^{2-}-\mathrm{S}$ and $\mathrm{NH}_{4}{ }^{+}-\mathrm{N}$; differences in macrophyte oxygen transfer rates, density of microbial groups and temperature and the relative proportions of removal pathways of organic matter. Valuable insights into the parallel and interacting processes of a constructed wetland aid improved conceptualization and design of a constructed wetland system. The simplified batch hydraulic regime of the system modelled in this implementation of CWM1 in AQUASIM allowed a focus on the biokinetics of CWs. However, porous media hydrodynamics, i.e. effect of dispersion, heterogeneity and dead zones must be considered for a realistic simulation and proper fit of the model to most operating CWs. For this, it is suggested that finite elements or finite difference models be used to describe water flow instead of the continuous stirred-tank reactor considered in this application (Langergraber et al., 2009). In pilot wetlands it is desirable that concentrations be tied to their locations, thereby creating the possibility of having aerobic, anoxic and anaerobic zones in the modelled wetland, as opposed to a "suspended culture". This can be achieved with use of biofilm models, with substrate conversion and bacteria growth combined with mass transport limitations into and within the biofilm matrix.

This model provides a promising tool for studying the dynamics of the key processes governing COD and nutrient dynamics in the wetland system, which is anticipated to promote an increased understanding of the performance aspects and sound conceptualization and design of constructed wetland systems. The CWM1 equations are based on commonly accepted Activated Sludge Models (ASMs), which enhances communication between wetland scientists as it introduces a kind of 'common language'. Due to the widespread application of the ASMs, literature provides much guidance for their stoichiometric and kinetic parameters values as these models already have been applied in many case studies.

\section{Conclusion}

CWM1 was successfully implemented in AQUASIM software. The model was applied to data from unplanted and planted experimental batch operated constructed wetland mesocosms to simulate the transformation and degradation of $\mathrm{COD}, \mathrm{NH}_{4}{ }^{+}-\mathrm{N}$ and $\mathrm{SO}_{4}{ }^{2-}-\mathrm{S}$. Based on the model output the principal conclusions are:

(i) The model was able to provide a reasonable fit to experimental data with the addition of physical oxygen re-aeration, plant and sorption processes.

(ii) Sensitivity analysis showed the parameters with the highest sensitivities to be those related with micro-organisms kinetics and sorption processes.

(iii) Plant root oxygen transfer rate varied with plant species and temperature. More oxygen was released to the mesocosms by plants at low temperature. Nevertheless, the oxygen transferred to the mesocosms by both plant root release and physical reaeration was insufficient compared with the oxygen demand of the wastewater. 
(iv) The better performance of the planted mesocosms was simulated well with a higher bacterial population than that of the unplanted mesocosms. Higher bacterial population was found at low temperature that high temperature.

(v) COD degradation was mainly through anaerobic processes under these specific experimental conditions. $\mathrm{SO}_{4}{ }^{2-}-\mathrm{S}$ was used as an electron acceptor for COD removal and was depleted quickly at the beginning of incubations.

(vi) $\mathrm{NH}_{4}{ }^{+}-\mathrm{N}$ was adsorbed on the gravel rapidly and further removed when the mesocosms were drained and the gravel exposed to the air. Nitrification and plant uptake of $\mathrm{NH}_{4}{ }^{+}-\mathrm{N}$ did not contribute significantly to the decline of $\mathrm{NH}_{4}^{+}-\mathrm{N}$ in the experimental mesocosms.

\section{Acknowledgement}

The authors are grateful to the Dutch Government through NUFFIC-NFP fellowship for the financial support provided for this research.

\section{Appendix A.}

Table A1

Mathematical equations for plant related process, physical re-aeration, adsorption-desorption processes as implemented in AQUASIM alongside the CWM1.

\begin{tabular}{ll}
\hline Process & Process rate \\
\hline Plant growth $\mathrm{NH}_{4}{ }^{+}-\mathrm{N}$ & $\frac{1}{d \times e p s} \times K_{p l} \times \frac{S_{-N H}}{K_{p n h}+S_{-} \mathrm{NH}} \times X_{p i}$ \\
Plant growth $\mathrm{NO}_{3}{ }^{-}-\mathrm{N}$ & $\frac{1}{d \times e p s} \times K_{p l} \times \frac{S_{-} \mathrm{NO}}{K_{p n o}+S_{-} \mathrm{NO}} \times \frac{K_{p n h}}{K_{p n h}+S_{-} \mathrm{NH}} \times X_{p i}$ \\
Plant degradation & $\frac{1}{d \times e p s} \times K_{\text {degrad }} \times X_{p d}$ \\
Plant decay & $\frac{1}{d \times e p s} \times b_{p} \times X_{p i}$ \\
Plant oxygen leaching rate & $\frac{K_{\text {rol }}}{d \times e p s} \times \exp \left(\left(S_{-} \mathrm{O}_{\text {sat }}-S_{-} \mathrm{O}\right)-1\right)$ \\
Physical reaeration & $K_{l a} \times\left(S_{-} \mathrm{O}_{\text {sat }}-S_{-} \mathrm{O}\right)$ \\
COD adsorption & $\omega \times\left(k S_{-} \mathrm{COD} \times X_{-}-X_{-} \mathrm{COD}_{\mathrm{Ad}}\right)$ \\
Ammonia adsorption & $a l p h a \times S_{-} \mathrm{NH}-\frac{X_{-N H}}{\text { PartitionCoefficient }} 1 / m$ \\
\hline
\end{tabular}

Table A2

Parameter and variable description and value.

\begin{tabular}{|c|c|c|c|}
\hline Parameter & Description & Unit & Value \\
\hline$d$ & Rooting depth & $\mathrm{m}$ & 0.5 \\
\hline eps & Matrix material porosity as fraction & & 0.27 \\
\hline$K_{p l}$ & Plant relative growth rate, function of season & $1 / \mathrm{d}$ & 0.033 \\
\hline$K_{p n h}$ & Ammonium half-saturation coefficient for plant growth & $\mathrm{g} \mathrm{NH}_{4}{ }^{+}-\mathrm{N} / \mathrm{m}^{3}$ & 0.3 \\
\hline$X_{p i}$ & Living plant biomass & $\mathrm{g}$ COD plant $/ \mathrm{m}^{2}$ & $0-300$ \\
\hline$K_{\text {pno }}$ & Nitrate half-saturation coefficient for plant growth & $\mathrm{g} \mathrm{NO}_{3}{ }^{-}-\mathrm{N} / \mathrm{m}^{3}$ & 0.1 \\
\hline$K_{\text {degred }}$ & First order plant physical degradation constant & $1 / \mathrm{d}$ & 0.01 \\
\hline$X_{p d}$ & Dead standing plant biomass & $\mathrm{g}$ COD plant $/ \mathrm{m}^{2}$ & $0-300$ \\
\hline$b_{p}$ & Decay coefficient for living plant material, function of season & & 0.002 \\
\hline$K_{\text {rol }}$ & Root oxygen loss parameter as per day & $\mathrm{m} / \mathrm{d}$ & \\
\hline$S_{-} \mathrm{O}_{\text {sat }}$ & Oxygen saturation concentration & $\mathrm{mg} \mathrm{O}_{2} / 1$ & \\
\hline$K_{l a}$ & Oxygen reaeration coefficient & $1 / \mathrm{d}$ & \\
\hline$\omega$ & First-order exchange rate & $1 / \mathrm{h}$ & $0.1-1$ \\
\hline$k \_S_{-} C O D$ & Empirical coefficient for COD adsorption & $\mathrm{mg}_{\mathrm{COD}} \mathrm{kg}_{\text {substrate }}{ }^{-1}$ & $1-3$ \\
\hline$X_{-} \mathrm{COD}_{\mathrm{Ad}}$ & Concentration of sorbed COD & $\mathrm{gCOD} / \mathrm{m}^{3}$ & \\
\hline alpha & Specific sorption rate coefficient & $1 / \mathrm{d}$ & 2 \\
\hline PartitionCoefficient & Solid-liquid (ammonium) partition coefficient & $1 / \mathrm{kg}$ gravel & 3 \\
\hline$m$ & Freundlich isotherm exponent & & 0.5 \\
\hline
\end{tabular}




\section{References}

Allen, W.C., Hook, P.B., Biederman, J.A., Stein, O.R., 2002. Temperature and wetland plant species effects on wastewater treatment and root zone oxidation. J. Environ. Qual. 31 (3), 1010-1016.

Baptista, J.D.C., Donnelly, T., Rayne, D., Davenport, R.J., 2003. Microbial mechanisms of carbon removal in subsurface flow wetlands. Water Sci. Technol. 48 (5) 127-134.

Bezbaruah, A.N., Zhang, T.C., 2005. Quantification of oxygen release by bulrush (Scirpus validus) roots in a constructed treatment wetland. Biotechnol. Bioeng. 89(3), 308-318.

Brisson, J., Chazarenc, F., 2009. Maximizing pollutant removal in constructed wetlands: should we pay more attention to macrophyte species selection? Sci. Total Environ. 407 (13), 3923-3930.

Brix, 1999. Functions of macrophytes in constructed wetlands. Water Sci. Technol 29 (4), 71-78.

Brix, H., 1997. Do macrophytes play a role in constructed treatment wetlands? Water Sci. Technol. 35 (5), 11-17.

Caffrey, J.M., Kemp, W.M., 1991. Seasonal and spatial patterns of oxygen production, respiration and root-rhizome release in Potamogeton perfoliatus L. and Zoster marina L. Aquat. Bot. 40 (2), 109-128.

Faulwetter, J.L., Gagnon, V., Sundberg, C., Chazarenc, F., Burr, M.D., Brisson, J. Camper, A.K., Stein, O.R., 2009. Microbial processes influencing performance of treatment wetlands: a review. Ecol. Eng. 35 (6), 987-1004.

Gagnon, V., Chazarenc, F., Comeau, Y., Brisson, J., 2007. Influence of macrophyte species on microbial density and activity in constructed wetlands. Water Sci. Technol. 56 (3), 249-254.

García, J., Aguirre, P., Barragán, J., Mujeriego, R., Matamoros, V., Bayona, J.M., 2005. Effect of key design parameters on the efficiency of horizontal subsurface flow constructed wetlands. Ecol. Eng. 25 (4), 405-418.

Haberl, R., 1999. Constructed wetlands: a chance to solve wastewater problems in developing countries. Water Sci. Technol. 40 (3), 11-17.

Henrichs, M., Langergraber, G., Uhl, M., 2007. Modelling of organic matter degradation in constructed wetlands for treatment of combined sewer overflow. Sci. Total Environ. 380 (1-3), 196-209.

Honda, Y., Matsumoto, J., 1983. The effect of temperature on the growth of microbia film in a model trickling filter. Water Res. 17 (4), 375-382.

Imfeld, G., Braeckevelt, M., Kuschk, P., Richnow, H.H., 2009. Monitoring and assessing processes of organic chemicals removal in constructed wetlands. Chemosphere 74 (3), 349-362.

Jespersen, D.N., Sorrell, B.K., Brix, H., 1998. Growth and root oxygen release by Typha latifolia and its effects on sediment methanogenesis. Aquat. Bot 61 (3) 165-180.

Kadlec, R.H., 2000. The inadequacy of first-order treatment wetland models. Ecol Eng. 15 (1-2), 105-119.

Kalyuzhnyi, S.V.,Fedorovich, V.V., 1998. Mathematical modelling of competition between sulphate reduction and methanogenesis in anaerobic reactors. Bioresour. Technol. 65 (3), 227-242.

Kivaisi, A.K., 2001. The potential for constructed wetlands for wastewater treatment and reuse in developing countries: a review. Ecol. Eng. 16 (4), 545-560.

Kotsyurbenko, O.R., 2005. Trophic interactions in the methanogenic microbial community of low-temperature terrestrial ecosystems. FEMS Microbiol. Ecol. 53 (1), $3-13$.

Kumar, J.L.G., Zhao, Y.Q., 2011. A review on numerous modeling approaches for effective, economical and ecological treatment wetlands. J. Environ. Manag. 92 (3), 400-406.

Langergraber, G., 2007. Simulation of the treatment performance of outdoor subsurface flow constructed wetlands in temperate climates. Sci. Total Environ. 380 (1-3), 210-219.

Langergraber, G., 2008. Modeling of processes in subsurface flow constructed wetlands: a review. Vadose Zone J. 7 (2), 830-842.

Langergraber, G., Rousseau, D.P.L., Garcia, J., Mena, J., 2009. CWM1: a general model to describe biokinetic processes in subsurface flow constructed wetlands. Wate Sci. Technol. 59 (9), 1687-1697.

Lew, B., Tarre, S., Belavski, M., Green, M., 2004. UASB reactor for domestic wastewater treatment at low temperatures: a comparison between a classical UASB and hybrid UASB-filter reactor. Water Sci. Technol. 49 (11-12), 295-301.

Llorens, E., Saaltink, M.W., Garcia, J., 2011a. CWM1 implementation in RetrasoCodeBright: first results using horizontal subsurface flow constructed wetland data. Chem. Eng. J. 166 (1), 224-232.

Llorens, E., Saaltink, M.W., Poch, M., García, J., 2011b. Bacterial transformation and biodegradation processes simulation in horizontal subsurface flow constructed wetlands using CWM1-RETRASO. Bioresour. Technol. 102 (2), 928-936.
McBride, G.B., Tanner, C.C., 1999. Modelling biofilm nitrogen transformations in constructed wetland mesocosms with fluctuating water levels. Ecol. Eng. 14 (1-2), 93-106.

Meysman, F.J., Middelburg, J.J., Herman, P.M.J., Heip, C.H.R., 2003. Reactive transport in surface sediments. I. Model complexity and software quality. Comput. Geosci. 29 (3), 291-300

Moutsopoulos, K.N., Poultsidis, V.G., Papaspyros, J.N.E., Tsihrintzis, V.A., 2011. Simulation of hydrodynamics and nitrogen transformation processes in HSF constructed wetlands and porous media using the advection-dispersionreaction equation with linear sink-source terms. Ecol. Eng. 37 (9), 1407-1415.

Ojeda, E., Caldentey, J., Saaltink, M.W., Garcia, J., 2008. Evaluation of relative importance of different microbial reactions on organic matter removal in horizontal subsurface-flow constructed wetlands using a 2D simulation model. Ecol. Eng. $34(1), 65-75$.

Puigagut, J., Villaseñor, J., Salas, J. Bécares, E García, J. 2007. Subsurface-flow constructed wetlands in Spain for the sanitation of small communities: a comparative study. Ecol. Eng. 30 (4), 312-319.

Ragusa, S.R., McNevin, D., Qasem, S., Mitchell, C., 2004. Indicators of biofilm development and activity in constructed wetlands microcosms. Water Res. 38 (12), 2865-2873.

Reichert, 1998. AQUASIM 2.0-User Manual Computer Program for the Identification and Simulation of Aquatic Systems. Swiss Federal Institute for Environmental Science and Technology (EAWAG), CH-8600 Dubendorf, Switzerland.

Reichert, P., 1995. Design techniques of a computer program for the identification of processes and the simulation of water quality in aquatic systems. Environ. Softw. 10 (3), 199-210.

Rousseau, D.P.L., 2005. Performance of constructed treatment wetlands: modelbased evaluation and impact of operation and maintenance. Ph.D. Thesis. Ghent University, Ghent, Belgium, available from http://biomath.ugent.be/ publications/download/.

Rousseau, D.P.L., Vanrolleghem, P.A., De Pauw, N., 2004. Model-based design of horizontal subsurface flow constructed treatment wetlands: a review. Water Res. 38 (6), 1484-1493.

Sanchez, E., Rivero, R.M., Ruiz, J.M., Romero, L., 2004. Changes in biomass, enzymatic activity and protein concentration in roots and leaves of green bean plants (Phaseolus vulgaris L. cv. Strike) under high NH4NO3 application rates. Sci. Hortic. 99 (3-4), 237-248

Solano, M.L., Soriano, P., Ciria, M.P., 2004. Constructed wetlands as a sustainable solution for wastewater treatment in small villages. Biosyst. Eng. 87 (1), 109-118.

Stein, O.R., Hook, P.B., 2005. Temperature, plants, and oxygen: how does season affect constructed wetland performance? J. Environ. Sci. Health A Tox. Hazard. Subst. Environ. Eng. 40 (6-7), 1331-1342.

Stein, O.R., Biederman, J.A., Hook, P.B., Allen, C., 2006. Plant species and temperature effects on the $\mathrm{k}-\mathrm{C}^{*}$ first-order model for COD removal in batch-loaded SSF wetlands. Ecol. Eng. 26 (2), 100-112.

Stein, O.R., Borden-Stewart, D.J., Hook, P.B., Jones, W.L., 2007. Seasonal influence on sulfate reduction and zinc sequestration in subsurface treatment wetlands. Water Res. 41 (15), 3440-3448.

Ström, L., Mastepanov, M., Christensen, T., 2005. Species-specific effects of vascular plants on carbon turnover and methane emissions from wetlands. Biogeochemistry $75(1), 65-82$.

Tanner, 2001. Plants as ecosystem engineers in subsurface-flow treatment wetlands. Water Sci. Technol. 44 (11-12), 9-17.

Taylor, C.R., 2009. Selecting plant species to optimize wastewater treatment in Constructed Wetlands. (M.S. thesis). Montana State University, Bozeman.

Tunçsiper, B., 2009. Nitrogen removal in a combined vertical and horizontal subsurface-flow constructed wetland system. Desalination 247 (1-3), 466-475.

Tyroller, L., Rousseau, D.P.L., Santa, S., García, J., 2010. Application of the gas tracer method for measuring oxygen transfer rates in subsurface flow constructed wetlands. Water Res. 44 (14), 4217-4225.

Vymazal, 2007. Removal of nutrients in various types of constructed wetlands. Sci. Total Environ. 380 (1-3), 48-65.

Vymazal, J., 2011. Plants used in constructed wetlands with horizontal subsurface flow: a review. Hydrobiologia, 1-24.

Wiessner, A., Kappelmeyer, U., Kuschk, P., Kästner, M., 2005. Sulphate reduction and the removal of carbon and ammonia in a laboratory-scale constructed wetland. Water Res. 39 (19), 4643-4650.

Wu, M.Y., Franz, E.H., Chen, S., 2001. Oxygen fluxes and ammonia removal efficiencies in constructed treatment wetlands. Water Environ. Res. 73 (6), 661-666.

Wynn, T.M., Liehr, S.K., 2001. Development of a constructed subsurface-flow wetland simulation model. Ecol. Eng. 16 (4), 519-536. 